\title{
KEANEKARAGAMAN FUNGI MIKORIZA ARBUSKULA (FMA) PADA RHIZOSFER Desmodium spp. ASAL PT. CIBALIUNG SUMBERDAYA, BANTEN
}

\author{
Diversity Arbuscular Mychorrizal Fungi from Desmodium spp. PT. Cibaliung \\ Sumberdaya, Banten
}

Sri Muryati, Irdika Mansur, dan Sri Wilarso Budi

Program Studi Silvikultur Tropika, Departemen Silvikultur Tropika, Fakultas Kehutanan IPB

\begin{abstract}
Ecosystem damage as a result of mining activity is very harmful to the environment. One of the strategy repairing the condition of post-mining land is to use legume cover crops, one type of legume cover crops is Desmodium spp., that has ability to form a symbiosis with AMF and rhizobium. The aim of this study was to determine the diversity of AMF from the four types of rhizosphere Desmodium spp. from PT. Cibaliung Sumber Daya, Banten with different types of host plants. The sampling technique of soil and roots were done by non propotional method. Soil samples were trapped with some types of host plants. Spores were isolated by wet-seaving and decanting technique, then the density of spores was measured and identified. The results showed an increasing number of spore and diversity of AMF. The number of spore before trapped was 10-89 spores per $20 \mathrm{~g}$ soil then increased to 16-114 spores per $20 \mathrm{~g}$ soil. While the AMF diversity before trapped found only 9 type of spores, consists of 8 type Glomus and 1 type Acaulospora. After trapped increased to 26 spores type AMF consists of 23 type of Glomus and 3 type of Acaulospoara. The root colonization was in range of $22.2-95.5 \%$
\end{abstract}

Key word: Desmodium spp., Cibaliung, Cover crops.

\section{PENDAHULUAN}

\section{Latar Belakang}

Penggunaan jenis tanaman penutup tanah merupakan salah satu alternatif dalam memperbaiki kondisi lahan pasca penambangan secara alami. Tanaman penutup tanah memiliki fungsi meningkatkan produktivitas tanah (fisik, kimia dan biologi), menyumbangkan nutrisi bagi pertumbuhan tanaman pokok, menekan pertumbuhan gulma, menjaga kelembaban tanah, dan melindungi tanah dari terpaan langsung air hujan yang dapat menyebabkan hilangnya lapisan atas tanah (Evans et al. 1988 ; Ding et al. 2006).

Indonesia memiliki beberapa jenis tanaman penutup tanah yang telah banyak dikembangkan pada beberapa perusahaan tambang seperti Centrosema pubescens, Calopogonium mucunoides, Pueraria javanica dan Mucuna spp. Namun jenis-jenis ini memiliki kelemahan, yaitu bersifat merambat dan melilit sehingga perusahaan membutuhkan biaya ekstra dalam pemeliharaan agar tidak mengganggu pertumbuhan tanaman pokok. Beberapa perusahaan pertambangan lebih memilih mengimpor biji rumput dan legum dari luar negeri yang bersifat tidak melilit agar mengurangi biaya perawatan (Mansur 2010). Oleh karena itu, upaya pengembangan jenis alternatif yang dapat tumbuh secara alami perlu dilakukan untuk mengevaluasi kekurangan dari jenis yang biasa digunakan (Hasanah 2014).
Jenis legum penutup tanah yang banyak dikenal sebagai tanaman pastura dan legum hijauan serta memiliki potensi untuk dikembangkan pada lahan pasca tambang yaitu Desmodium spp., merupakan tanaman herbal berkayu yang tumbuhnya menjalar namun tidak melilit pada tanaman pokok, selalu hijau, dan menghasilkan serasah melimpah sebagai sumber bahan organik tanah (Evans et al. 1988). Hasil penelitian Zuhelmi et al. (2015) D. heteropyllum di lahan pasca tambang kapur memiliki persentase tutupan lahan mencapai $17.09 \%$ selama 8 MST. Sedangkan hasil penelitian Hasanah (2014) yang melakukan pengukuran terhadap luasan penutup lahan hingga 8 MST menunjukkan bahwa $D$. heterophyllum mencapai $100 \%$; $D$. ovalifolium dan $D$. triflorum masing-masing mencapai $95.2 \%$ dan $65.8 \%$. Hal ini menunjukkan bahwa tanaman Desmodium spp. mempunyai kemampuan tutupan lahan yang cepat.

Peningkatan kemampuan Desmodium spp. dalam penyerapan unsur hara selain dibantu oleh rhizobium, juga erat kaitannya dengan adanya simbiosis dengan Fungi Mikoriza Arbuskula (FMA). FMA merupakan salah satu mikroorganisme tanah yang membantu dalam siklus unsur hara. Struktur hifa yang panjang dan halus dapat menjelajah ke dalam tanah untuk menyerap air, unsur hara makro, dan mikro yang tidak dapat dijangkau oleh akar (Goltapeh et al. 2013). Simbiosis FMA dengan inang dapat meningkatkan ketahanan inang terhadap serangan penyakit akar (Suharti et al. 2011), hifa juga menghasilkan glomalin yang berperan 
mengatur stabilisasi agregasi tanah (Rillig dan Steinberg 2002), FMA juga dapat membantu dalam proses fitoremediasi pada lahan tercemar logam berat (Suharno dan Sancayaningsih 2013).

FMA dalam asosiasinya mempunyai kisaran inang yang sangat luas, asosiasi FMA mencapai $80 \%$ dengan tanaman teristerial. Namun tingkat efektifitas setiap tanaman inang berbeda-beda, karena beberapa jenis FMA tertentu menunjukkan spesifikasi untuk memilih dan berasosiasi dengan jenis tanaman inang tertentu. Jenis tanaman inang dan kondisi lingkungan akan sangat menentukan tingkat kolonisasi akar, jumlah spora dan keragaman tipe spora (Goltapeh et al. 2013).

Setiap jenis FMA memiliki kemampuan yang berbeda terhadap pertumbuhan tanaman, sehingga pemilihan jenis isolat FMA yang kompetibel dangan tanaman inang penting dilakukan (Prafithriasari dan Nurbaity 2010). Oleh karena itu, diperlukan upaya mempelajari potensi keanekaragaman FMA pada Desmodium spp. perlu dilakukan agar dapat meningkatkan kemampuan pertumbuhan Desmodium spp. sebagai tanaman penutup tanah pada lahan pasca tambang.

\section{Tujuan}

Penelitian ini bertujuan untuk mengetahui keanekaragaman FMA dari rhizosfer 4 jenis Desmodium spp. asal PT. Cibaliung Sumberdaya, Banten dengan menggunakan berbagai jenis tanaman inang.

\section{BAHAN DAN METODE}

\section{Waktu dan Tempat}

Penelitian dilaksanakan mulai bulan Desember 2014 sampai April 2015. Pengambilan sampel tanah dan akar Desmodium spp. pada rhizosfer 4 jenis Desmodium spp. yang tumbuh pada wilayah kerja PT. Cibaliung Sumberdaya Kecamatan Cimanggu, Kabupaten Pandeglang, Banten yang belum dilakukan kegiatan penambangan. Pelaksanaan penelitian dilaksanakan di Laboratorium Teknologi Mikoriza dan Kualitas Bibit dan Rumah Kaca Departemen Silvikultur, Fakultas Kehutanan, Institut Pertanian Bogor.

\section{Bahan dan Alat}

Bahan yang digunakan dalam penelitian ini adalah contoh tanah dari 4 jenis tanaman Desmodium spp. yang diambil dari kawasan PT. Cibaliung Sumberdaya, aquades, larutan $\mathrm{KOH} 20 \%, \mathrm{HCl} 0.1 \mathrm{M}$, larutan destaining, $\mathrm{HCl} 0.1 \mathrm{M}$, larutan sukrosa $60 \%$, larutan trypan blue, polyvynil alcohol lactogliserol (PVLG), larutan Melzer's, benih Sorghum vulgare, benih Peureria javanica, benih D. ovalifolium, zeolit, Hyponex merah.

Alat yang digunakan dalam penelitian ini adalah autoclave, oven, centrifuge, micro pippet, gelas objek, kaca penutup, satu set penyaring dengan diameter lubang 500, 125 dan $63 \mu \mathrm{m}$, timbangan analitik, gunting, kertas label, optilab camera, cawan petri, polybag, sprayer, dissecting microscope, compound microscope.

\section{Prosedur Kerja}

\section{Pengambilan Contoh Tanah}

Contoh tanah dan akar tanaman diambil dari rhizosfer 4 jenis Desmodium spp. yang terdapat pada kawasan PT. Cibaliung Sumberdaya. Pengambilan contoh tanah dan akar dilaksanakan dengan metode tidak proposional. Pengambilan contoh tanah dan akar Desmodium spp. dilakukan pada 4 titik pengamatan yaitu pada rhizosfer tanaman $D$. ovalifolium, $D$. heterophyllum, D. triflorum dan D. heterocarpon yang terdapat di lapangan dan merupakan tanaman yang tumbuh secara alami. Pengambilan contoh tanah dan tanaman dilakukan pada kedalaman $0-20 \mathrm{~cm}$ dan diameter $20 \mathrm{~cm}$ kemudian dimasukkan ke dalam polybag dan diberi label (Nusantara et al. 2012).

\section{Pengamatan Kolonisasi Akar}

Pewarnaan akar mengacu metode Clapp et al. (1996) dengan tahapan pewarnaan yaitu 1) akar dicuci hingga bersih dengan air destilata; 2) akar direndam dalam KOH $20 \%$ selama 48 jam; 3) akar dicuci dengan air hingga bersih dengan menggunakan saringan, kemudian direndam pada $\mathrm{HCl} 0.1 \mathrm{M}$; 4) tanpa dicuci akar direndam pada larutan larutan trypan blue selama 48 jam; 5) akar direndam dengan larutan destaining selama 24 jam; 6) akar dipotong dengan ukuran $1 \mathrm{~cm}$, kemudian akar disusun sejajar pada gelas objek dan ditutupi dengan kaca penutup. Persentase kolonisasi akar dihitung dengan rumus yang dikembangkan oleh Brundrett et al. (1996).

$\%$ Kolonisasi $=\frac{\sum \text { bidang pandang yang terkoloni }}{\sum \text { keseluruhan bidang pandang }} \mathrm{X} 100 \%$

\section{Isolasi dan Karakterisasi Tipe Spora FMA}

Isolasi spora FMA dari contoh tanah dilakukan dengan metode tuang saring basah (Pacioni 1992) dan dilanjutkan dengan sentrifugasi (Brundrett et al. 1996). Langkah-langkah dalam isolasi spora; 1) contoh tanah diambil sebanyak $20 \mathrm{~g}$ ditambahkan dengan air hingga $500 \mathrm{ml}$ diaduk; 2) suspensi tanah dituangkan ke penyaringan bertingkat dari atas ke bawah dengan ukuran 500, 125, dan $63 \mu \mathrm{m}$; 3) suspensi tanah yang tersaring pada saringan ukuran 125 dan $63 \mu \mathrm{m}$ dimasukkan ke dalam tabung reaksi lalu ditambahkan dengan larutan sukrosa $60 \%$ sebanyak $1 / 3$ bagiannya; 4) kemudian dilakukan sentrifugasi dengan kecepatan 2300 rpm selama kurang lebih 3 menit; 5) cairan yang agak bening di bagian tengah tabung (mengapung) merupakan peralihan antara larutan glukosa dengan air, disedot dengan menggunakan pipet untuk dicuci dan disaring dengan saringan $63 \mu \mathrm{m} ; 5)$ hasilnya ditempatkan dalam cawan petri dan diamati di bawah mikroskop untuk penghitungan kepadatan spora. Kepadatan spora dihitung dengan rumus:

Kepadatan spora $=\frac{\text { Jumlah spora }}{\text { Bobot tanah yang dianalisis }}$


Spesimen spora diawetkan dengan menggunakan polyvynil alcohol lactogliserol (PVLG) dan larutan Melzer's yang diletakkan pada satu kaca preparat. Pengamatan yang dilakukan dengan melihat ciri morfologi spora yaitu berdasarkan ukuran, warna, lapisan dinding spora, permukaan dinding spora dan reaksi dengan larutan Melzer's (Nusantara et al. 2012). Hasil pengamatan spora FMA dikarakterisasi sampai tingkat genus. Peubah yang diamati adalah tipe spora FMA dan kepadatan spora FMA pada contoh tanah.

\section{Kultur Trapping}

Pembutan kultur trapping (penangkaran) mengacu Brundrett et al. (1996) dengan menggunakan pot-pot kultur kecil. Media tanam yang digunakan berupa campuran tanah seberat $\pm 50 \mathrm{~g}$ dan batuan zeolit berukuran diameter $1-2 \mathrm{~mm}$ seberat $\pm 120 \mathrm{~g}$, media tanam disusun dengan urutan zeolit-contoh tanah-zeolit.

Sumber contoh tanah yang digunakan berasal dari rhizosfer 4 jenis Desmodium spp. terdiri dari $D$. ovalifolium, D. heterophyllum, D. triflorum dan $D$. heterocarpon yang tumbuh pada kawasan PT. Cibaliung Sumberdaya dan menggunakan 3 jenis tanaman inang terdiri dari $S$. vulgare, $P$. javanica dan $D$. ovalifolium. Kultur memiliki 12 kombinasi yang diulang sebanyak 7 kali sehingga terdapat 84 pot tanaman.

Pemeliharaan kultur meliputi penyiraman, pemberian hara, dan pengendalian hama secara manual. Panen dilakukan jika spora baru telah terbentuk. Spora digunakan dalam proses identifikasi. Ekstraksi dan identifikasi spora menggunakan teknik yang sama dengan ekstraksi dan identifikasi dari contoh tanah namun spora hasil trapping tidak menggunakan teknik sentrifugasi.

\section{Analisis Data}

Data berupa persentase kolonisasi akar, kepadatan spora, dan status keanekaragaman FMA dianalisis secara deskriptif.

\section{HASIL DAN PEMBAHASAN}

\section{Persentase kolonisasi akar}

Hasil pengamatan terhadap contoh tanah yang berasal dari rhizosfer 4 jenis Desmodium spp. berasal dari lahan tambang PT. Cibaliung Sumberdaya disajikan pada Tabel 1 .
Hasil pengamatan persentase kolonisasi akar pada 4 jenis tanaman Desmodium spp. terlihat bahwa semua sampel akar terdapat kolonisasi FMA dan persentase kolonisasi sangat tinggi yaitu dalam kisaran $92-100 \%$ (Tabel 1). Kolonisasi akar merupakan bentuk proses simbiosis antara akar tanaman inang dan FMA. Menurut Baptista et al. (2011) proses kolonisasi akar terbagi menjadi 4 tahapan yaitu sebelum infeksi, penetrasi hifa pada akar tanaman inang, hifa tumbuh dan berkembang pada sel akar dan tahapan akhir FMA akan menjalankan fungsinya membantu penyerapan hara dan air untuk tanaman inang.

Asosiasi FMA bersama Desmodium spp. dapat diketahui dengan terbentuknya struktur yang khas dari kolonisasi FMA pada akar tanaman inangnya. Struktur FMA dapat berupa hifa internal dan hifa eksternal, spora, vesikula, arbuskula, dan miselia. Hasil pengamatan pada sampel akar tanaman Desmodium spp., terbentuk struktur hifa internal dan eksternal, vesikula, arbuskula, dan spora (Gambar 1). Struktur yang dibentuk oleh spora FMA ini berfungsi dalam menjalankan peranan penting dalam proses asosiasi. Hifa terbentuk dari perkecambahan spora, yang berperan dalam menyerap unsur hara dan air dari luar ke dalam akar dan selanjutnya digunakan dalam proses pertumbuhan dan perkembangan tanaman inang. Struktur arbuskula memiliki bentuk seperti pohon, terbentuk dari cabang-cabang hifa intraradikal yang berada antara dinding sel dan membran sel. Arbuskula berperan penting sebagai tempat pertukaran unsur hara dan karbon antara FMA dan tanaman inang serta tempat penyimpanan sementara mineral, nutrisi, dan gula. Sedangkan vesikula merupakan struktur berdinding tipis yang terbentuk dari pembengkakan pada ujung hifa, berbentuk bulat, lonjong, atau tidak teratur. Vesikula berperan sebagai organ penyimpan cadangan makanan seperti lipid dan dalam waktu tertentu berperan sebagai spora yang merupakan alat pertahanan kehidupan FMA. Selanjutnya spora, merupakan organ perbanyakan diri FMA, terbentuk dari hifa ekstraradikal yang memiliki bentuk tunggul maupun berkoloni (sporocarps). Spora memiliki komposisi yang terdiri dari polisakarida, lipid, protein, dan kitin. Spora memiliki organ seperti mitokondria, retikulum endoplasma, dan vakuola. Dalam memperbanyak diri, spora terlebih dahulu mengalami perkecambahan untuk menghasilkan hifa untuk menginfeksi akar tanaman inangnya (Peterson et al. 2004; Simanungkalit et al. 2006).

Tabel 1 Jenis, jumlah spora dan persentase kolonisasi akar FMA pada sampel tanah sebelum trapping asal PT. Cibaliung Sumberdaya.

\begin{tabular}{|c|c|c|c|}
\hline Jenis tanaman & Jenis FMA & $\begin{array}{l}\text { Jumlah spora/20 g } \\
\text { contoh tanah }\end{array}$ & $\begin{array}{c}\text { kolonisasi akar } \\
(\%)\end{array}$ \\
\hline D. heteropylum & Glomus sp. 15, Glomus sp. 21 & 10 & 100 \\
\hline D. ovalifolium & $\begin{array}{l}\text { Glomus sp. } 16, \text { Glomus sp. } 20 \text {, } \\
\text { Acaulospora sp. } 3\end{array}$ & 17 & 92 \\
\hline D. triflorum & $\begin{array}{l}\text { Glomus sp. 1, Glomus sp. } 5 \text {, } \\
\text { Glomus sp. } 16\end{array}$ & 21 & 100 \\
\hline D. heterocarpon & Glomus sp. 4, Glomus sp. 9 & 89 & 100 \\
\hline
\end{tabular}



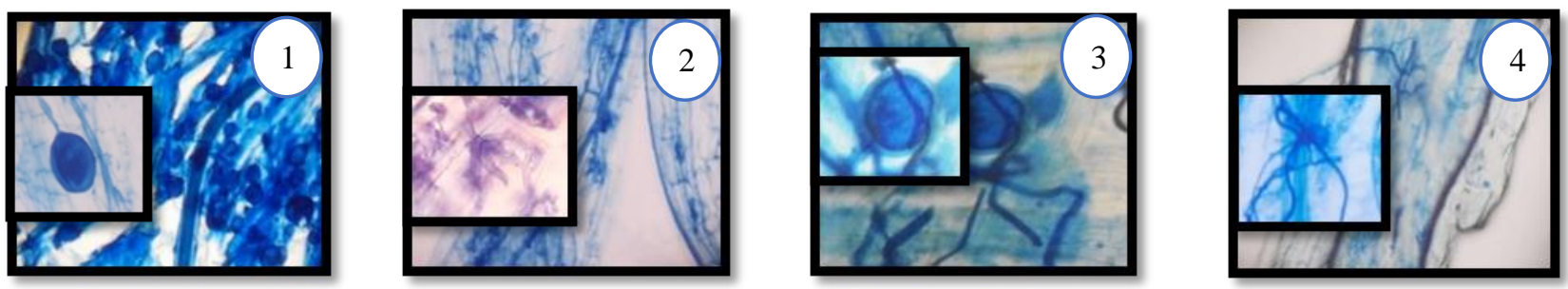

Gambar 1 Struktur FMA (a) Vesikula (b) Arbuskula (c) Spora (d) Hifa internal (Pembesaran 10 x)

Tabel 2 Jenis, jumlah spora dan kolonisasi akar FMA dari sampel tanah setelah kultur trapped asal dengan beberapa jenis tanaman inang.

\begin{tabular}{|c|c|c|c|c|}
\hline Sumber inokulum & $\begin{array}{l}\text { Jenis tanaman } \\
\text { inang }\end{array}$ & Jenis FMA & $\begin{array}{c}\text { Jumlah spora/20 g } \\
\text { contoh tanah }\end{array}$ & $\begin{array}{l}\text { \% kolonisasi } \\
\text { akar }(\%)\end{array}$ \\
\hline \multirow[t]{3}{*}{ D. heteropylum } & S. vulgare & Glomus sp. 2, Glomus sp. 20 & 18 & $\begin{array}{c}91.1 \\
\text { (sangat tinggi) }\end{array}$ \\
\hline & P. javanica & $\begin{array}{l}\text { Glomus sp. } 4 \text {, Glomus sp. } 11 \text {, } \\
\text { Glomus sp. } 17 \text {, Glomus sp. } 21 \text {, } \\
\text { Acaulospora sp. } 2\end{array}$ & 55 & $\begin{array}{l}22.2 \\
\text { (rendah) }\end{array}$ \\
\hline & D. ovalifolium & $\begin{array}{l}\text { Glomus sp. 1, Glomus sp. 3, } \\
\text { Glomus sp. 4, Glomus sp. 21, } \\
\text { Acaulospora sp. } 1\end{array}$ & 32 & $\begin{array}{c}64.4 \\
\text { (tinggi) }\end{array}$ \\
\hline \multirow[t]{3}{*}{ D. ovalifolium } & S. vulgare & $\begin{array}{l}\text { Glomus sp. 3, Glomus sp. } 6 \text {, } \\
\text { Glomus sp. } 15 \text {, Glomus sp. } 22\end{array}$ & 16 & $\begin{array}{c}73.3 \\
\text { (tinggi) }\end{array}$ \\
\hline & P. javanica & $\begin{array}{l}\text { Glomus sp. 3, Glomus sp. 4, } \\
\text { Glomus sp. } 8\end{array}$ & 28 & $\begin{array}{c}33.3 \\
\text { (sedang) }\end{array}$ \\
\hline & D. ovalifolium & Glomus sp. 1, Glomus sp. 7 & 20 & $\begin{array}{c}26.7 \\
\text { (sedang) }\end{array}$ \\
\hline \multirow[t]{3}{*}{ D. triflorum } & S. vulgare & $\begin{array}{l}\text { Glomus sp. } 8, \text { Glomus sp. } 11 \text {, } \\
\text { Glomus sp. } 22 \text {, Glomus sp. } 23\end{array}$ & 26 & $\begin{array}{c}88.9 \\
\text { (sangat tinggi) }\end{array}$ \\
\hline & P. javanica & $\begin{array}{l}\text { Glomus sp. 2, Glomus sp. 3, } \\
\text { Glomus sp. } 5\end{array}$ & 16 & $\begin{array}{l}37.8 \\
\text { (sedang) }\end{array}$ \\
\hline & D. ovalifolium & $\begin{array}{l}\text { Glomus sp. } 10 \text {, Glomus sp. } 11 \text {, } \\
\text { Glomus sp. } 20\end{array}$ & 42 & $\begin{array}{c}83.3 \\
\text { (sangat tinggi) }\end{array}$ \\
\hline \multirow[t]{3}{*}{ D. heterocarpon } & S. vulgare & $\begin{array}{l}\text { Glomus sp. 1, Glomus sp. } 4 \text {, } \\
\text { Glomus sp. } 9 \text {, Glomus sp. } 13 \text {, } \\
\text { Glomus sp. } 16, \text { Glomus sp. } 18 \text {, } \\
\text { Acaulospora sp. } 3\end{array}$ & 105 & $\begin{array}{c}95.5 \% \\
\text { (sangat tinggi) }\end{array}$ \\
\hline & P. javanica & $\begin{array}{l}\text { Glomus sp. 4, Glomus sp. } 9 \text {, } \\
\text { Glomus sp. } 10, \text { Glomus sp. } 11 \text {, } \\
\text { Glomus sp. } 14\end{array}$ & 114 & $\begin{array}{c}48.9 \\
\text { (sedang) }\end{array}$ \\
\hline & D. ovalifolium & $\begin{array}{l}\text { Glomus sp. 3, Glomus sp. 6, } \\
\text { Glomus sp. 9, Glomus sp. 10, } \\
\text { Glomus sp. 12, Glomus sp. } 19\end{array}$ & 65 & $\begin{array}{c}57.8 \\
\text { (tinggi) }\end{array}$ \\
\hline
\end{tabular}

Hasil pengamatan terhadap persentase kolonisasi akar setelah trapping menunjukkan nilai yang bervariasi. Bervariasinya persentase kolonisasi akar, salah satunya dipengaruhi oleh jenis tanaman inang. Pada tabel 2 terlihat bahwa penggunaan tanaman inang $S$. vulgare selalu memberikan nilai persentase kolonisasi akar paling tinggi pada semua perlakuan inokulum yaitu pada inokulum asal $D$. heteropylum $91.1 \%, D$. ovalifolium $91.1 \%$, D. triflorum $88.9 \%$, dan $D$. heterocarpon $95.5 \%$. Ini menunjukkan bahwa tanaman inang $S$. vulgare memiliki tingkat kecocokan yang tinggi terhadap FMA. Hal ini dimungkinkan karena tanaman memiliki sistem perakaran yang luas dan dalam, toleran terhadap lingkungan rumah kaca dan merupakan tanaman cepat tumbuh (Herryawan 2012).

Menurut Deptan (1990) tanaman sorgum memiliki akar-akar sekunder dua kali lebih banyak serta memiliki sistem perakaran dalam sehingga spora FMA dapat menginfeksi dengan lebih mudah. Selain itu juga sorgum memiliki kemampuan beradaptasi pada kisaran ekologi yang luas, sorgum dapat tumbuh pada kondisi yang sangat panas atau kondisi curah hujan tinggi, kemampuan adaptasi yang tinggi ini yang menyebabkan tanaman sorgum tetap tumbuh dengan baik pada kondisi rumah kaca. Sorgum juga merupakan jenis tanaman cepat tumbuh, sehingga tanaman ini akan cepat melakukan proses fotosintesis dan menghasilkan karbohidrat yang akan digunakan dalam proses pembentukan hifa intraradikal dalam akar tanaman inang.

Hasil pengamatan terhadap persentase kolonisasi akar bahwa sumber inokulum $D$. ovalifolium dengan tanaman inang $D$. ovalifolium menunjukkan nilai persentase kolonisasi akar sedang yaitu $26.7 \%$. Seharusnya kombinasi perlakuan ini dapat memberikan nilai persentase kolonisasi yang paling tinggi karena 
menggunakan sumber FMA indigenous asal D. ovalifolium. Menurut Delvian (2006) FMA indigenous memiliki potensi yang tinggi untuk membentuk kolonisasi yang ekstensif karena mengenali tanaman inangnya, selain itu FMA indigenous memiliki sifat toleransi yang lebih tinggi terhadap kondisi lingkungan dengan cekaman yang tinggi. Kemungkinan pada pemeliharaan terdapat faktor lain yang mempengaruhi proses kolonisasi akar, pengamatan pada akar tanaman inang $D$. ovalifolium menunjukkan bahwa akar tidak berkembang dengan baik, terlihat jumlah akar yang sedikit, dan tanaman terlihat layu dengan daun menguning. Hal ini disebabkan adanya serangan nematoda pada perakaran $D$. ovalifolium yang terbawa dari sumber inokulum tanah dari lapangan. Serangan nematoda ini menyebabkan perakaran membusuk dan terganggunya serapan hara dan air oleh tanaman. Schmidt et al. (2001) menyatakan bahwa tanaman Desmodium sp. rentan terhadap serangan nematoda, di Amerika Selatan pernah terjadi serangan nematoda pada pertanaman Desmodium sp. hingga menyebabkan tanaman layu, kerdil, daun menguning hingga menyebabkan kematian tanaman.

Kolonisasi akar paling rendah ditunjukkan oleh kombinasi antara sumber inokulum $D$. heteropylum dan tanaman inang $P$. javanica yaitu $22.2 \%$. Hal ini karena tingkat kecocokan antara tanaman inang $P$. javanica dengan sumber inokulum asal $D$. heteropylum yang rendah. Sedangkan penggunaan jenis tanaman inang yang lain tetap menunjukkan persentase kolonisasi yang tinggi hingga sangat tinggi yaitu pada $S$. vulgare $91.1 \%$ dan D. ovalifolium $64.4 \%$. Hal ini karena daya infektivitas dan efektivitas yang berbeda pada setiap inang, karena hanya inang yang disukai oleh FMA yang memberikan tanggapan simbiotik dan kolonisasi yang maksimal. Wulandari et al. (2014) menyatakan, inokulasi spora jenis Glomus sp. pada tanaman inang jagung, jarak pagar, dan bawang merah menghasilkan persentase kolonisasi masing-masing 58\%, 31\%, dan $56 \%$.

\section{Kepadatan spora FMA}

Hasil pengamatan kepadatan spora pada 4 inokulum tanah asal rhizosfer Desmodium spp. menunjukkan bahwa jumlah spora yang ditemukan sangat bervariasi yaitu dalam kisaran 10 - 89 spora per $20 \mathrm{~g}$ tanah (Tabel 1). Siklus hidup FMA dimulai ketika propagul berupa spora dan hifa mengalami kontak dengan inang yang sesuai. Hifa akan melakukan penetrasi dengan membentuk appresoria untuk masuk ke dalam sel akar tanaman inang. Hifa FMA akan berkembang ekstensif di dalam ruang interseluler dalam korteks, membentuk hifa intraradikal, kemudian membentuk arbuskula dan vesikula. Siklus akhir FMA akan membentuk organ pertahanan berupa spora (Smith and Read 2008).

Hasil pengamatan setelah trapping menunjukkan bahwa jumlah spora mengalami peningkatan, yaitu dari kisaran 10-89 spora per $20 \mathrm{~g}$ contoh tanah menjadi 16 114 spora per $20 \mathrm{~g}$ contoh tanah. Peningkatan jumlah spora dikarenakan adanya perlakuan trapping yang bertujuan untuk menstimulasi sporulasi yang terdapat di dalam tanah yang berasal dari lapangan. Setiap jenis FMA akan aktif pada periode waktu yang berbeda-beda, sebagian jenis FMA jumlahnya akan melimpah pada musim hujan sedangkan sebagian yang lain pada musim kemarau dan ada jenis FMA yang akan aktif sepanjang tahun (Oehl et al. 2009). Suharno et al. (2015) menambahkan peningkatan jumlah spora hasil trapping didukung dengan kondisi lingkungan rumah kaca yang terkontrol dan stabil, sehingga memberikan kesempatan spora yang diisolasi dari lapangan yang belum berkecambah mengalami perkecambahan dan membentuk spora baru.

Pada penelitian ini, masing-masing perlakukan menunjukkan jumlah spora yang bervariasi, namun terdapat kombinasi perlakuan tertentu yang cenderung menghasilkan jumlah spora yang lebih tinggi dibandingkan kombinasi lain, yaitu kombinasi yang terdapat perlakuan sumber inokulum $D$. heterocarpon dengan ketiga jenis tanaman inang, $S$. vulgare menghasilkan 105 spora, $P$. javanica 114 spora, dan D. ovalifolium 65 spora untuk $20 \mathrm{~g}$ contoh tanah. Data ini menunjukkan bahwa sumber inokulum asal $D$. heterocarpon memiliki spora yang memiliki efektivitas yang tinggi, hal ini sejalan dengan nilai persentase kolonisasi akar yaitu pada S. vulgare $95.5 \%, P$. javanica $48.9 \%$ dan $D$. ovalifolium $57.8 \%$. Selain tingkat efektivitas spora yang mendukung jumlah spora pada perlakuan kombinasi itu, dimungkinkan juga karena jumlah spora asal dari inokulum D. heterocarpon menunjukkan jumlah paling banyak dibandingkan sumber inokulum lain yaitu 89 spora per $20 \mathrm{~g}$ contoh tanah (Tabel 1). Jumlah spora ini berkaitan dengan meningkatnya kesempatan spora untuk menginfeksi akar. Sejalan dengan hasil penelitian Nurbaity et al. (2011) inokulasi spora dengan perlakuan jumlah spora $(0,50,100$ dan 150 spora) pada tanaman kentang menunjukkan bahwa persentase kolonisasi akar yang berbeda yaitu $0 \%, 31 \%, 37 \%$ dan $52 \%$, terlihat bahwa perlakuan jumlah spora paling tinggi yaitu 150 spora memberikan nilai persentase kolonisasi akar paling tinggi pula. Ditambahkan hasil penelitian Widiastuti dan Sukarno (2005), perlakuan inokulasi spora Acaulospora tuberculata dengan 3 dosis jumlah spora (200, 350 dan 500 spora) pada bibit kelapa sawit menunjukkan bahwa perlakuan 500 spora A. tuberculata berpengaruh nyata dalam meningkatkan bobot basah tajuk, bobot kering akar dan total bobot basah dan kering bibit kelapa sawit.

\section{Keragaman spora FMA}

Hasil isolasi dan identifikasi spora asal 4 inokulum rhizosfer Desmodium spp. ditemukan 2 genus FMA yaitu genus Glomus 8 tipe spora dan genus Acaulospora 1 tipe spora (Tabel 1). Keragaman jenis tanaman inang, tipe spora, dan kondisi lingkungan seperti kondisi tanah secara langsung menunjukkan respon yang berbeda terhadap persentase kolonisasi, jumlah spora, dan keragaman tipe spora (Quilambo 2003).

Hasil pengamatan terhadap kultur trapping menunjukkan terjadinya peningkatan keragaman tipe spora pada semua kombinasi perlakuan. Keragaman tipe spora genus Glomus pada contoh tanah sebelum trapping terdiri dari 8 tipe spora kemudian berkembang menjadi 23 tipe spora FMA, sedangkan genus Acaulospora yang awal hanya ditemukan 1 tipe spora bertambah menjadi 3 tipe spora FMA. Terlihat bahwa spora genus Glomus 
selalu mendominasi keragaman jenis spora sebelum dan setelah penangkaran, menurut Wanda et al. (2015), spora genus Glomus merupakan jenis spora yang paling dominan ditemukan pada beberapa kondisi ekosistem, karena jenis FMA ini memiliki kisaran inang yang luas. Hasil penelitian Hartoyo et al. (2011), keanekaragaman FMA pada rizosfer Centella asiatica menunjukkan dari total 14 spesies yang ditemukan 10 spesies adalah tipe Glomus. Ditambahkan hasil penelitian Delvian (2006), pengamatan yang dilakukan sebanyak 5 kali pada lokasi yang sama menunjukkan total 13 tipe spora, yang terdiri dari Glomus sebanyak 8 tipe, Acaulospora sebanyak 3 tipe dan Gigaspora dan Sclerocystis masing-masing 1 tipe spora.

Hasil pengamatan terhadap persentase kolonisasi akar, jumlah spora, dan keragaman jenis menunjukkan bahwa kombinasi inokulum asal $D$. heterocarpon dengan ketiga tanaman inang juga selalu menunjukkan nilai paling tinggi yaitu pada tanaman inang $S$. vulgare 95.5\% (sangat tinggi), 105 spora dengan 7 tipe spora (Glomus 6 tipe dan Acaulospora 1 tipe), P. javanica $48.9 \%$ (sedang), 114 spora dengan 5 tipe spora Glomus dan D. ovalifolium $57.8 \%$ (tinggi), 65 spora dengan 6 tipe spora Glomus.

\section{SIMPULAN}

Keanekaragaman FMA dari 4 rhizosfer Desmodium spp. asal PT. Cibaliung Sumberdaya, Banten sebelum dan setelah trapping menujukkan peningkatan jumlah spora, keragaman jenis FMA, sedangkan nilai persentase kolonisasi akar relatif bervariasi. Hasil pengamatan jumlah spora menunjukkan peningkatan dari 10-89 spora per $20 \mathrm{~g}$ tanah meningkat menjadi 16-114 spora per $20 \mathrm{~g}$ tanah, keragaman tipe spora terdiri dari 8 tipe Glomus dan 1 Acaulospora menjadi 23 tipe Glomus dan 3 tipe Acaulospora. Sedangkan persentase kolonisasi akar dari 92 - 100\% dan setelah kultur trapping menjadi $22.2-95.5 \%$.

\section{DAFTAR PUSTAKA}

Baptista P, Tavares RM, Neto TL. 2011. Signaling in ectomycorrhizal symbiosis establishment. In: Rai M dan Varma A, editor. Diversity and Biotechnology of Ectomycorrhizae. Portugal (PT). Springer.

Brundrett M, Bougher N, Dell B, Grove T, Malajczuk N. 1996. Working with Mychorrizas In Forestry and Agriculture. Canberra (AU): Australian Centre for International Agricultural Research.

Clapp JP, Fitter AH, Merryweather JW. 1996. Arbuskular mycorrhizas. In: Hall GS, Lasserre P, Hawksworth DL, Editor. Methods for the Examination of Organismal Diversity in Soils and Sediments. Wallingford, Oxon (UK). CAB International.

Delvian. 2006. Dinamikan sporulasi cendawan mikoriza arbuskula [Karya Tulis]. Medan (ID): Universitas Sumatera Utara.

[Deptan] Departemen Pertanian. 1990. Teknologi Budidaya Sorgum. Jayapura (ID): Balai Informasi Pertanian Irian Jaya.
Ding G, Liu X, Herbert S, Novak J, Amarasiriwardena D, Xing B. 2006. Effect of cover crop management on soil organic matter. Geoderma. 130: 229-239.

Evans DO, Joy RJ, Chia CL. 1988. Cover crop for orchards in Hawaii. Research Extension Series 094.

Goltapeh EM, Danesh YZ, Prasad R, Varma A. 2008. Mycorrhizal fungi: what we know and what should we know?. In : Varma A, editor. Mycorrhiza: State of the Art, Genetics and Molecular Biology, EcoFunction, Biotechnology, Eco-Physiology, Structure and Systematics. India (IN). Springer.

Hasanah NI. 2014. Pengembangan Desmodium spp. sebagai tanaman penutup tanah dalam reklamasi lahan pasca tambang [Tesis]. Bogor (ID): Institut Pertanian Bogor.

Herryawan KM. 2012. Perbanyakan inokulum fungi mikoriza arbuskular (FMA) secara sederhana. Jurnal Pastura. 2 (2): 57-60.

Hartoyo B. 2012. Efektivitas fungi mikoriza arbuskula pada penggunaan pupuk fosfat alami dan pengarunya terhadap pertumbuhan, biomassa dan produksi asiatikosida pegagan (Centella asiatica L. Urban) di andosol [Disertasi]. Bogor (ID): Institut Pertanian Bogor.

Mansur I. 2010. Teknik Silvikultur untuk Reklamasi Lahan Bekas Tambang. Bogor (ID): SEAMEO BIOTROP.

Nurbaity A, Sunarto T, Hindersah R, Solihin A, Kalay M. 2011. Fungi mikoriza arbuskula asal Pendeglang, Jawa Barat sebagai agens hayati pengendali nematoda sista kentang. Jurnal Agrotropika. 16 (2): 57-61.

Nusantara AP, Bertham YH, Mansur I. 2012. Bekerja dengan Fungi Mikoriza Arbuskula. Bogor (ID): Kerjasama SEAMEO BIOTROP dengan IPB press.

Oehl F, Sieverding E, Ineichen K, Mader P, Wiemken A, Boller T. 2009. Distinct sporulation dynamics of arbuscular mycorrhizal fungal communities from different agroecosystems in long-term microcosms. Journal Agriculture Ecosystems and Environment. 134: 257-268.

Pacioni G. 1992. Wet-sieving and decanting techniques for the extraction of spores of vesicular-arbuskulas fungi. 317- 322. In : Norris JR, Read DJ, Varma AK, editor. Methods In Microbiology. London (GB). Academic Press.

Peterson RL, Massicotte HB, Melville LH. 2004. Mychorrhizas : Anatomy and Cell Biology. Ottawa (CA). NRC Research Press.

Prafithriasari M, Nurbaity A. 2010. Infektivitas inokulan Glomus sp. dan Gigaspora pada berbagai kompoisi media zeolit-arang sekam dan pengaruhnya terhadap pertumbuhan tanaman sorgum (Sorghum bicolor). Jurnal Agrikultura. 21 (1): 3945.

Quilambo OA. 2003. The vesicular-arbuskula mycorrhizal symbiosis. African Journal of Biotechnology. 2 (12): 539-546.

Rillig MC, Steinberg PD. 2002. Glomalin production by an Arbuscular Mycorrhizal Fungus: A mechanism of habitat modification. Soil Biology \& Biochemistry. 34: 1371-1374. 
Simanungkalit RD, Saraswati R, Hastuti RD, Husen E. 2006. Bakteri penambat fosfat. Di Dalam: Simanungkalit RD, Suriadikarta DA, Saraswati R, Setyorini D, Hartatik W, Editor. Pupuk Organik dan Pupuk Hayati. Bogor (ID): Badan Penelitian dan Pengembangan Pertanian.

Schmidt A, Peters M, Kraft R S. 2001. Desmodium heterocarpon (L.) DC. Subsp. Ovalifolium (Prain) Ohashi. Pagina. 1-13.

Smith SE, Read DJ. 2008. Mycorrhizal Symbiosis. London (GB). Academic Press.

Suharno, Sancayaningsih RP. 2013. Fungi mikoriza arbuskula: potensi teknologi mikorizoremediasi logam berat dalam rehabilitasi lahan tambang. Jurnal Bioteknologi. 10 (1): 31- 42.

Suharno, Tanjung RH, I VA, Sufaati S. 2015. Keragaman fungi mikoriza arbuskula pada tumbuhan pokem [Setaria italica (L). Beauv.] dengan metode trapping. Jurnal Biologi Papua. 7 (2): 68-77.

Suharti N, Habazar T, Nasir N, Dachryanus dan Jamsari. 2011. Induksi ketahanan jahe terhadap penyakit layu Rastonia solanecearum ras 4 menggunakan fungi mikoriza arbuskula (FMA) indigenus. Jurnal HPT Tropika. 11 (1) : 102-111.

Wanda AR, Yuliani, Trimulyono G. 2015. Keanekaragaman Cendawan Mikoriza Vesikula Arbuskula (MVA) di hutan pantai nepa Sampang Madura berdasarkan gradien salinitas. Lentera Bio. 4(3): 180-186.

Widiastuti H, Sukarno N. 2005. Penggunaan spora cendawan mikoriza arbuskula sebagai inokulum untuk meningkatkan pertumbuhan dan serapan hara bibit kelapa sawit. Jurnal Manara Perkebunan. 73 (1): 26-34.

Wulandari G, Suwirmwn, Noli ZA. 2014. Kompetibiltas spora Glomus hasil isolasi dari Rhizosfer Macaranga triloba dengan tiga jenis tanaman inang. Jurnal Biologi Universitas Andalas. 3 (2): 116-122.

Zuhelmi V, Aneloi Z, Suwirmen. 2015. Pengatur tumbuh giberalin (GA3) dalam upaya reklamasi lahan pasca tambang batu kapur [Prosiding Seminar Nasional Biodeversitas dan Ekologi Indonesia]. Padang (ID). Jurusan biologi FMIPA, Universitas Andalas. 
Lampiran 1 Karakteristik tipe spora FMA dari 4 rhizosfer Desmodium spp. asal PT. Cibaliung Sumberdaya, Banten

\begin{tabular}{llc}
\hline Tipe Spora & \multicolumn{1}{c}{ Karakteristik Morfologi } & Reaksi dengan Melzer's \\
\hline & $\begin{array}{l}\text { Spora bulat, berwarna orange jernih, permukaan spora } \\
\text { halus dan tebal, ukuran 96.91- 112.598 x 93.38-155.56 } \\
\mu \mathrm{m} .\end{array}$ & Tidak bereaksi \\
& & \\
\hline
\end{tabular}

Glomus sp. 1

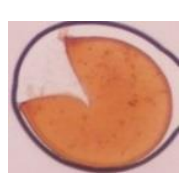

Glomus sp. 2

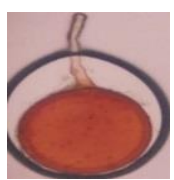

Glomus sp. 3

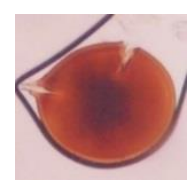

Glomus sp. 4

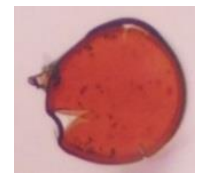

Glomus sp. 5
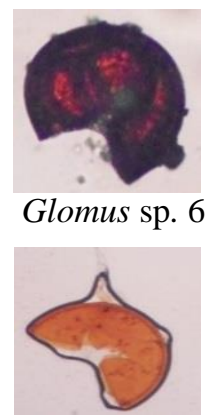

Glomus sp. 7

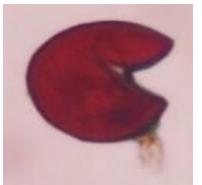

Glomus sp. 8

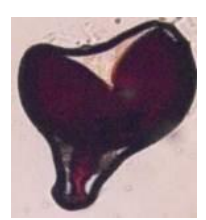

Spora bulat, berwarna merah tua, permukaan spora halus dan tebal , ukuran 91.33-151.17 x 83.317-161.37 $\mu \mathrm{m}$.
Spora bulat, berwarna orange, permukaan spora halus dan tipis, ukuran 87.50-139.10 x 119.44-125 $\mu \mathrm{m}$.

Spora bulat, berwarna orange, permukaan spora kasar dan tebal, ukuran 60.93-128.245 x 78.52-177.78 $\mu \mathrm{m}$.

Spora bulat, berwarna orange tua, permukaan spora halus dan tebal, ukuran 99.54-114.06 x 91.64-110.98 $\mu \mathrm{m}$.

Spora bulat, berwarna orange kemerahan, permukaan halus dan tebal, ukuran 116.21-137.90 x 117.198$142,23 \mu \mathrm{m}$.

Spora bulat, berwarna merah kehitaman dan motif warna orange, permukaan spora halus dan tebal, ukuran 82.87-93.11 x 68.77-90.65 $\mu \mathrm{m}$.

Spora bulat, berwarna orange, permukaan spora halus dan tebal, ukuran 156.975 x $149.233 \mu \mathrm{m}$.

Spora bulat, berwarna merah tua, permukaan spora kasar dan tebal, ukuran 93.11-161.32 x 112.99-197,22 $\mu \mathrm{m}$.
Tidak bereaksi

Tidak bereaksi

Tidak bereaksi

Tidak bereaksi

Tidak bereaksi

Tidak bereaksi

Tidak bereaksi

Tidak bereaksi 


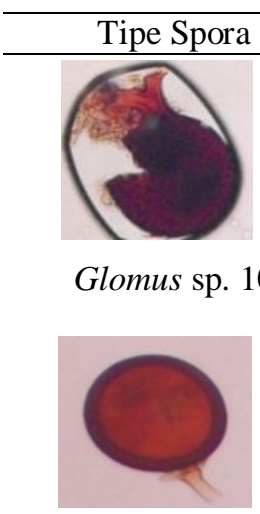

Glomus sp. 11

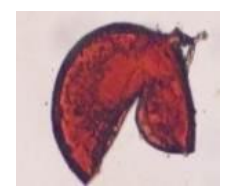

Glomus sp. 12

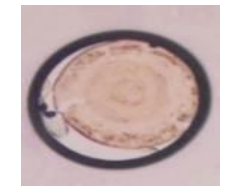

Glomus sp. 13

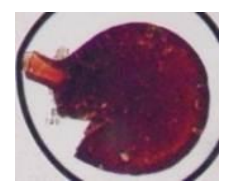

Glomus sp. 14

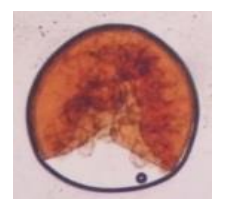

Glomus sp. 15

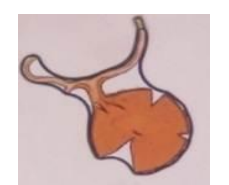

Glomus sp. 16

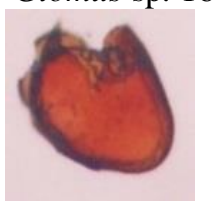

Glomus sp. 17

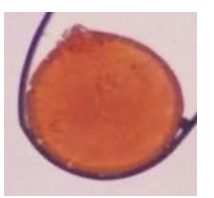

Glomus sp. 18

Karakteristik Morfologi

Spora bulat, berwarna merah tua, permukaan spora kasar dan tipis, ukuran 117.19-134.86 x 89.12-125.53 $\mu \mathrm{m}$.

Spora bulat, berwarna merah tua pada dinding dan orange bagian dalam spora, permukaan spora kasar dan tebal ukuran 88.89-116.21 x 59.81-117.19 $\mu \mathrm{m}$.

Spora bulat, berwarna merah bercak orange, permukaan spora halus dan tipis ukuran 109.31$137.90 \times 108.93-142.23 \mu \mathrm{m}$.

Spora bulat, jernih, permukaan spora halus dan tipis, ukuran 97.78 x $93.15 \mu \mathrm{m}$.

Spora bulat, berwarna merah kehitaman, permukaan spora kasar dan tebal, ukuran 82.87 x $68.77 \mu \mathrm{m}$.

Spora bulat, berwarna orange, permukaan spora kasar dan tipis, ukuran $175.03 \times 171.90 \mu \mathrm{m}$.

Spora bulat, berwarna cokelat muda, permukaan spora kasar dan tipis, ukuran 110.09 x $107.58 \mu \mathrm{m}$.

Spora elips, berwarna orange muda, permukaan spora halus dan tebal, ukuran 137.53 x $117.23 \mu \mathrm{m}$.

Spora elips, berwarna orange, permukaan spora kasar dan tebal, ukuran 106.20 x $87.28 \mu \mathrm{m}$.
Reaksi dengan Melzer's

Tidak bereaksi

Tidak bereaksi

Tidak bereaksi

Tidak bereaksi

Tidak bereaksi

Tidak bereaksi

Tidak bereaksi

Tidak bereaksi

Tidak bereaksi 


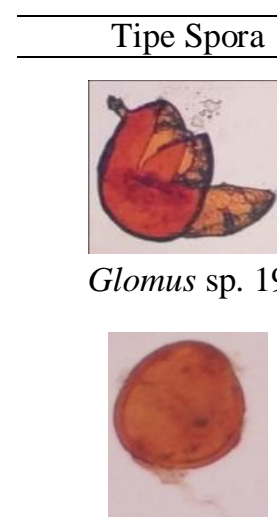

Glomus sp. 20

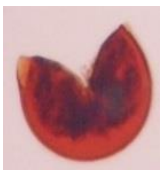

Spora bulat, berwarna merat tua-orange, permukaan spora halus dan tebal, ukuran 81.25-150.01 x 134.38$147.22 \mu \mathrm{m}$.

Glomus sp. 21

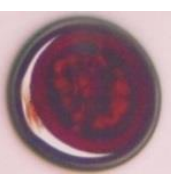

Spora bulat, berwarna merah-bercak orange tua, permukaan spora halus dan tebal, ukuran 105.21133.04 x 93.76-161.37 $\mu \mathrm{m}$.

Glomus sp. 22

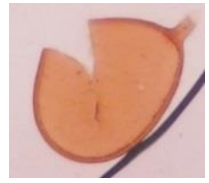

Spora bulat, berwarna kuning jernih, permukaan spora halus dan tebal, ukuran 137.72 x $123.63 \mu \mathrm{m}$.

Tidak bereaksi

Glomus sp. 23

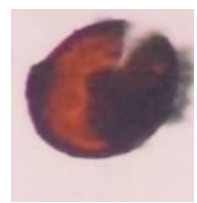

Spora bulat, berwarna cokelat kehitaman, permukaan

Bereaksi spora kasar dan tebal, ukuran 107.812 x $98.449 \mu \mathrm{m}$.

\section{Acaulospora sp. 1}

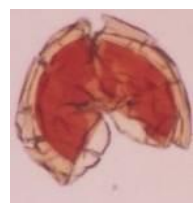

Spora bulat, berwarna Orange, permukaan spora kasar dan tebal, ukuran 143.89 x $139.06 \mu \mathrm{m}$.

Tidak bereaksi

Acaulospora sp. 2

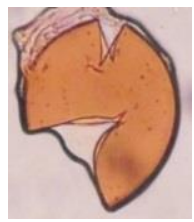

Spora elips, berwarna merah orange, permukaan spora halus dan tebal, ukuran 101.32 x $103.09 \mu \mathrm{m}$.

Tidak bereaksi Acaulospora sp. 3 